\title{
The Effect of Dividend Announcements on Stock Returns for Companies Listed on the Main Board of the Kuala Lumpur Stock Exchange
}

\author{
NUR-ADIANA HIAU ABDULLAH \\ ROSEMALIZA ABDUL RASHID \\ YUSNIDAH IBRAHIM \\ School of Finance and Banking \\ Universiti Utara Malaysia
}

\begin{abstract}
Stock market reactions to the announcements of final dividend increases, decreases and no changes are empirically analyzed in an emerging market environment. A standard event study methodology is adopted to examine the price reactions of 120 listed companies surrounding sixty days of the announcement dates. Although prior studies in developed countries postulate that dividend decreases are associated with negative abnormal returns, such a reaction was not found in the Malaysian capital market. The evidence nevertheless shows that dividend increases lead to positive abnormal returns, supporting the Information Content Hypothesis, Jensen's Free Cash Flow Hypothesis and Agency Cost Theory. As for the no change dividend announcements, no clear pattern of cumulative average abnormal returns could be observed.
\end{abstract}

\begin{abstract}
ABSTRAK
Reaksi pasaran saham terhadap pengumuman pembayaran dividen akhir dalam tiga keadaan iaitu peningkatan, penurunan dan tidak berubah telah dianalisis di dalam suasana pasaran menyerlah. Metodologi kajian peristiwa digunakan untuk meneliti reaksi harga pada sekitar enam puluh hari dari tarikh pengumuman bagi 120 syarikat tersenarai. Walau pun kajian lepas di negara membangun menunjukkan pengumuman penurunan pembayaran dividen memberi kesan pulangan luar biasa negatif, reaksi ini tidak dijumpai di dalam pasaran modal di Malaysia. Namun begitu, bukti menunjukkan bahawa pengumuman peningkatan bayaran dividen membawa kepada pulangan luar biasa positif, yakni menyokong hipotesis kandungan maklumat, hipotesis aliran tunai bebas Jensen dan teori kos agensi. Bagi pengumuman pembayaran dividen yang tidak berubah, tiada pola purata pulangan luar biasa kumulatif yang jelas dapat dilihat.
\end{abstract}

\section{INTRODUCTION}

Ever since the work of Fama et al. (1969), event studies have become an essential part of empirical research in the area of finance. These studies normally examine the effects of specific economic events' announcement on stock returns. A significant difference between the realized and expected returns are linked to the wealth effects generated by the announcements of the events.

Acknowledgment: We record our sincere appreciation to Universiti Utara Malaysia for the financial support. As for the remaining errors, we take full responsibility. 
Various theories have been forwarded to explain the impact of dividend announcements on stock returns. The theoretical underpinnings for these studies were derived from Miller and Modigliani (1961) who introduced the information content of dividend hypothesis. They explicitly suggest that managers used cash dividend announcements to signal changes in their expectation about the future prospect of a company when the markets are imperfect. This is supported by the cash flow signaling theory (Bhattacharya, 1979, 1980; John and Williams, 1985; Miller and Rock, 1985) which theorized that dividend changes are explicit signals about future earnings, sent intentionally and at some costs by management to the company and its stockholders. Another explanation for the form of information content in dividend announcements comes from Jensen's (1986) free cash flow hypothesis, which associates increase in dividend with less free cash flow and thus less tendency to over-invest, for example accepting marginal investment projects that have negative net present value (NPV). The signaling theory thus hypothesizes that a management decision to increase dividend will lead to a higher stock price while a decision to decrease dividend, conversely, will reduce the stock prices.

The objective of this paper is to consider the effects of dividend increase, decrease and no change announcements against the stock returns for listed companies in an emerging market environment, i.e., the Malaysian capital market. Many studies have been carried out in the developed market but little evidence exists for the emerging market (Glen et al. 1997; Mansor and Subramaniam, 1992). The outcome of these announcements could either be positive or negative depending upon the information content brought by such announcements whether they are interpreted as good or bad news announcement; that is whether investors associate dividend announcements as positive or negative signals against the prospect of a company.

The organization of this paper is as follows: section two provides the corporate finance theoretical background on the effect of dividend announcements on stock returns. This is followed by section three that reviews the empirical evidence on behavior of stock returns surrounding the announcements. This is followed by a description of the data and methodology in section four. Section five analyzes the results and section six concludes the paper.

\section{THEORETICAL BACKGROUND ON THE EFFECT OF DIVIDEND ANNOUNCEMENTS ON STOCK RETURNS}

Several theories concerning the relationship of dividend policies and stock returns have been documented in the financial literature as share price maximization is the central focus in finance. In 1961, Miller and Modigliani (M\&M) advanced the Dividend Irrelevance Theory which theorizes that in a perfect world where there is no corporate and personal taxes, no transaction and flotation costs, no single individual who can affect a security's price through his/her trade, all individuals have similar expectations with respect to a company's future investment and profit, and where a company has a planned and fixed investment policy (Ross et al. 1999), the value of a company and thus its share prices are unaffected by the distribution of dividends. Hence, the value of a company is determined solely by the earning power and the risk of its assets but not by the manner in which it splits its earnings stream between retained earnings and dividends. They argued that an increase in dividend payment should result in a capital loss to existing shareholders and these two will offset each other. Dividend changes are theorized as involving the tradeoff between the current income and the future selling price. Though, the validity of the perfect world is empirically unjustified, the Irrelevance Theory is crucial for providing the background for the formulation of further theories that account for various imperfections in the real world.

One such imperfection which is critical to the development of theories related to dividend is the asymmetric information problem which lends importance to the Signaling Theory. This is also referred to as the information content of dividend hypothesis. According to the theory, also founded by $M \& M$, dividend announcements are hypothesized to have information content, whereby managers use cash dividend announcement to signal 
changes in their expectation about the future prospect of the company when the markets are imperfect. The information content inherent in a dividend announcement would cause shareholders to react to the announcement and thus influence the company share prices. There are however debates with respect to the form of information content that is being conveyed to the market through the dividend announcements.

Built on the premise of the information content of dividend hypothesis, other theories have been developed to explain the nature of information content in a dividend announcement. The cash flow signaling theory, also referred to as the cash flow hypothesis, developed by Bhattacharya (1979, 1980), John and Williams (1985) and Miller and Rock (1985), theorized that dividend changes are explicit signals about the current and/or future cash flows, sent intentionally and at some costs by management to the company and its stockholders. Miller and Rock assumed asymmetric information with respect to the magnitude of a company's current internal cash flow, but symmetric information to its level of planned investment and value of assets. They studied the impact of dividend payment. According to them, cash dividends payment is normally associated with a company's operating cash flow assuming the amount of investment and external financing is constant. If a company announced dividend payment which is greater than expected by the market, it reveals an increase of the company's future cash flow which brings an upward movement of its stock price. The theory thus hypothesized that an increase (decrease) in dividend will lead to an increase (decrease) in stock prices where the levels of cash dividends are associated with the levels of permanent earnings which would affect the stock value.

Jensen (1986), on the other hand, proposed a theory which is widely known as the free cash flow hypothesis. According to Jensen, the free cash flow exists in a company when there are excess funds left over after taking into account all positive net present value projects. He argues that a conflict of interest between shareholders and managers over the payout policies of these free cash flows could explain the stock price reaction. The theory predicts that stock prices will increase if there is unexpected dividend payment. It associates an increase in dividend with less free cash flow and thus less tendency to over-invest, for example accepting marginal investment projects that have negative NPVs. In other words, changes in dividend payment signal changes in investment policy.

Similar predictions could also be inferred from the agency cost theory forwarded by Easterbrook (1984). According to him, the separation of ownership from control would encourage managers to misuse the company's resources for their personal gain. A regular cash dividend payment ensures that managers are alert with their actions. If there is a reduction in dividend, this would increase access to internally generated funds where there is a likelihood of the management to allocate a greater proportion of the company's resources into perquisites. In such a case, the agency cost theory associates cash dividend decrease with a reduction in a company's equity value, hence a negative price effect is expected out of the announcement.

\section{EMPIRICAL EVIDENCE ON THE EFFECT OF DIVIDEND ANNOUNCEMENTS ON STOCK RETURNS}

Numerous empirical studies have been carried out to determine the stock market reactions to dividend announcements (Aharony and Swary, 1980; Asquith and Mullins, 1983; Impson, 1997; Impson and Karafiath, 1992; Jin, 2000; Michaely et al. 1995; Yoon and Starks, 1995). The results of these studies provide support for the information content of dividend hypothesis. In general, the studies documented a significant and positive relationship between dividend announcements and stock prices. In other words, an announcement of a dividend increase will be followed by an increase in stock price while an announcement of a dividend decrease will lead to a reduction in share price. Empirical evidence on price reactions to dividend announcements was carried out in a wide variety of settings. Some of which include the announcements of dividend initiation, omission, increase, decrease or a combination of several dividend announcements. 
Table 1

Implications of Corporate Finance Theories in Predicting the Sign of Abnormal Returns Associated with Dividend Announcements

\begin{tabular}{|l|l|l|}
\hline Theory & $\begin{array}{l}\text { Dividend } \\
\text { announcement }\end{array}$ & Expected price effect \\
\hline $\begin{array}{l}\text { Cash Flow Signaling Theory/ } \\
\text { Information Content Hypothesis }\end{array}$ & $\begin{array}{l}\text { Increase } \\
\text { Decrease }\end{array}$ & $\begin{array}{l}\text { Positive price effect } \\
\text { Negative price effect } \\
\text { (signal current and/or } \\
\text { future cash flows) }\end{array}$ \\
$\begin{array}{l}\text { Jensen's Free Cash Flow } \\
\text { Hypothesis }\end{array}$ & $\begin{array}{l}\text { Increase } \\
\text { Decrease } \\
\text { Nositive price effect } \\
\text { (signal changes in } \\
\text { investment policy) }\end{array}$ \\
Agency Cost Theory & Decrease & $\begin{array}{l}\text { Negative price effect } \\
\text { (misuse of funds) }\end{array}$ \\
\hline
\end{tabular}

Past studies focusing on dividend initiations document a positive relationship between stock prices and dividend initiation announcements. Asquith and Mullins (1983) initiated the work on determining the effect of dividend initiations on stock prices based on a premise that the best measure of an unanticipated dividend event is the initiation of dividends. Using a sample of 168 companies that initiated dividends or resumed paying after a ten-year gap from 1963 to 1980 , they found a significant positive excess return following dividend initiation announcements. Hence, they concluded that dividend initiation announcements do convey useful information.

Healy and Palepu (1988) extended the work of Asquith and Mullins (1983) by looking at the nature of earning changes surrounding a dividend initiation or omission announcements. This study utilized two sets of sample. One sample consisted of 131 companies that payed dividends for the first time or those that stopped paying dividend for 10 years while the other sample included 172 companies that retrained dividends for the first time or after paying dividends for the last 10 years. The results of the study showed a significant earning increase/decrease for at least one year prior to the dividend initiation/omission announcements. In addition, the study also found a correlation between abnormal stock price reactions to dividend initiations or omissions and earning changes during and following the announcement year.

The third study by Mitra and Owers (1995) looked at the information content of dividend hypothesis by focusing on the relationship between security price reaction to a dividend announcement and the company's information environment. They used the following company-specific characteristics as the proxy variables for the information environment: size, number of institutions holding the company's equity, percentage of institution equity holdings and number of analysts following the company. The sample used in the study consists of 80 dividend initiations announced by companies between January 1976 and December 1987. The data was obtained from the CRSP daily master and was cross-checked against the Moody's Annual Dividend Record and/or the Wall Street Journal Index. For each proxy, the sample was further divided into a low level of information environment and a medium/high level of information environment. The market model was used to estimate the abnormal returns surrounding the dividend initiation announcements. The results of this study were in line with previous studies with regard to the associa- 
tion of dividend initiation announcements where a highly significant positive CAR of $2.19 \%$ with a $z$ statistic of 5.08 during the two day announcement period $(t=-1,0)$ was observed.

A more recent study by Jin (2000) which focused on the apparent heterogeneity in the stock prices reaction to dividend initiation announcements, shows two distinct categories of dividendinitiating companies resulting from company specific characteristics. For one category, initiation is a value-increasing event, while for the other, initiation is a value-decreasing event. He suggested that the basis of market reaction to dividend initiation announcements should be the net effect of the costs and benefits of a new dividend program which varies from one company to another. The sample used in his study consists of 157 companies that were screened from the initial data set of companies on the CRSP NYSE/ AMEX from the period 1973 to 1993.

Utilizing the expanded market model to estimate the abnormal returns during the announcement and defining the market reaction to the initiation announcements of the companies as a 2day cumulative abnormal return (CAR), Jin found 102 companies $(64.9 \%)$ had positive cumulative abnormal returns and 55 companies $(35.2 \%)$ have negative abnormal returns. The sample is later divided into two sub-groups according to whether the CAR at announcement is positive (Group P) or negative (Group N). A preliminary analysis was executed on the full sample and the two subsamples. Jin concluded that "negative announcement CARs tend to occur when the benefits of dividend initiation are likely to be small; the economic impact of the dividend initiation is affected by the perceived value of the dividend program as a future information release mechanism; and the extent to which the manager/stockholders agency problem is mitigated". A positive relationship between stock prices and dividend initiation announcements is also supported by other studies done by Venkatesh (1989), and Lipson, Maquieira et al. (1998).

In contrast to dividend initiations, there is evidence that shows dividend reductions and omissions recorded significant negative abnormal returns following dividend reduction or omission announcements. This is shown in the work of
Dielman and Oppenheimer (1984), Eades et al. (1985), Ghosh and Woolridge (1988), Impson (1997) and Woolridge (1983).

In an attempt to investigate the capital market reaction to quarterly dividend announcements, Aharony and Swary (1980) utilized a sample of 3,399 quarterly dividend announcements made by 149 industrial companies selected from the companies traded on the New York Stock Exchange from 1963 to 1976 . The sample was obtained from Compustat tapes of the Investor Management Science, CRSP tapes, Wall Street Journal Index and annual cumulative issues of Moody's Dividend Record. They divided the sample into three subgroups: a) no changes in dividends, b) increases in dividends and c) decreases in dividends. The market model is used to calculate the abnormal returns in the days preceding and following the earnings and dividends announcements. The results showed positive abnormal returns for companies announcing dividend increases and negative abnormal returns for companies announcing dividend decreases for twenty days surrounding the announcement dates. This indicates strong support for the information content of dividend hypothesis. Specifically, Aharony and Swary (1980) found that quarterly dividend announcements provide information beyond that contained in quarterly earnings announcements. Further evidence on dividend increases and decreases can also be observed in the works of Charest (1978) and Pettit (1972).

Impson and Karafiath (1992) extended the analysis of stock market reactions to dividend by focusing on the different reactions to the proportion of increasing and decreasing payout ratio for both dividend increase and decrease announcements. The study tested the following two hypotheses. First, they hypothesized that abnormal returns are positively correlated with dividend changes and negatively correlated with payout ratio changes. Second, they suggested that there are more negative abnormal returns for payout ratios increases as compared to payout ratio decreases. A sample consisting of 116 dividend announcements made by companies listed on the NYSE/AMEX CSRP tape during the period 1970 to 1986 was used in the study. To ensure compatibility between samples, only those companies with at least a 20 percent 
change in dividends were included. The sample is further divided into payout ratio increases and decreases. The hypotheses were tested using a standard event study methodology and cross-sectional regression. Results of the study showed that the share price reaction is not significant when it is associated to dividend increases, whether the payout ratio increases or decreases. However for dividend decreases, there exists a strong negative abnormal return on days $t=0$ and +1 for both payout ratio increase and decrease cases. The cross sectional regression results further support this finding where it shows that the payout ratio change is not statistically significant to explain the abnormal returns except for the percentage change in dividend.

A subsequent study by Impson (1997) compared share price reactions to dividend decrease announcements by public utilities against share price reactions to dividend decrease announcements by unregulated industrial companies. He anticipated a stronger market response to dividend decrease announcements by public utilities as compared to unregulated companies. The sample used in his study was obtained from the Dow Jones News Retrieval electronic database and CRSP database from 1974 to 1993 . There were 46 dividend decrease announcements and 19 dividend omission announcements by public utilities (including electric, natural gas, and electric/gas) which were selected; whereas the number of sample for unregulated industrial companies were 574 reductions and 86 omissions during the same period. A quarter to quarter dividend reductions and omissions were used. Impson developed two regression models to detect the difference between the abnormal returns of the two groups. The results showed strong negative abnormal returns on both days of the event, i.e, period $t=1$ and $t=0$ for both public utility and the control sample (unregulated industrial companies). Evidence from the study also documented significantly stronger negative market responses to dividend decrease announcements by public utilities as compared to unregulated companies even when yield, pricestandardized dividend change, company size and Tobin's Q differences were considered.

The effects of dividend announcements on share prices have also been examined in coun- tries other than the United States (US). For instance, Lonie et al. (1996) conducted a study to check on the United Kingdom (UK) stock market's reaction to dividend announcements. The sample was obtained from the Financial Times during the period January to June 1991, that consisted of 620 companies that made annual dividend announcements. This was then subdivided into 354 companies that had declared a dividend increase, 114 companies which declared a dividend decrease and 152 companies which did not make changes in their dividend payment. The market model was used to calculate the abnormal return during the announcement period $(t=1$ and $t=0$ ). The results of the study showed a significant positive abnormal return for the dividend increasing companies. Conversely, a negative abnormal return was recorded for the dividend decreasing groü. The no change in dividend sample reported a significant positive abnormal return on day $t=-1$.

Another study using a UK data set by Balachandran et al. (1999) focused specifically on market reaction to interim dividend reductions. A sample of 242 interim dividend reductions for the period 1986 to 1993 was utilized in the study. The sample was further subdivided into two categories consisting of 142 initial interim dividend reductions and 100 subsequent interim dividend reductions. The subsequent interim dividend reductions sample was further subdivided into two groups: (1) interim dividend reductions are greater then prior final dividend reductions and (2) interim dividend reductions are less than prior final dividend reductions. Dividend announcement dates were obtained from the Annual Financial News Summary while the dividend per share data was extracted from the Microview Plus Database. The following five models were used to determine the abnormal return surrounding the announcement dates: market model, mean adjusted return model, market adjusted return model, one lead/ lag model and two lead/lag model. In general, all the models generated similar results whereby statistically significant negative price reactions were observed following interim dividend reductions. Furthermore, stronger price reactions were observed in the case of initial dividend reductions as compared to subsequent to prior final dividend reductions. 
As for evidence from emerging market, not too much effort has been made to identify the effects of dividend announcements (Glen et al., 1997). Only one study has been found in the Malaysian capital market, i.e by Mansor and Subramaniam (1992). They conducted a study to examine the effect of dividend and earnings announcements on share prices using a weekly data. A sub-sample was created where they looked at dividend increase, dividend decrease, earning increase and earning decrease. Their results showed that dividend and earning increase is associated with positive effects whereas dividend and earning decrease lead to negative reactions. They then created a new sample by further categorizing the original sample into four sub-samples: dividend and earning increase; dividend and earning decrease; dividend increase but earning decrease; and dividend decrease but earning increase. From these new sub-samples, Mansor and Subramaniam found that none of the abnormal returns provide a significant effect when the dividend and earning changes are in opposite direction.

\section{THE SAMPLE AND METHODOLOGY}

This section explains the sample used to examine the effect of dividend announcements on stock returns. This is followed by an explanation of the benchmark used to estimate the abnormal returns.

\section{Population and Sample}

The population of the study is the announcements of final dividend changes for 187 observations listed on the Kuala Lumpur Stock Exchange (KLSE) from the year 1996 to 1999, which was categorized into three classifications: 'increasing', 'decreasing' and 'no change'. The classification was made based on the work of Impson (1997) whereby a reduction greater than 10 percent on the amount of dividend paid from the previous payment $\left[\left(D_{t}-D_{t-1}\right) / D_{t-1}\right]$ is categorized as decreasing announcements. However, this classification has been modified by using final-to-final reductions instead of quarter-to-quarter reductions used by Impson. This modification is necessary due to the inconsistency of the interim dividend payments among listed companies in Malaysia. The same method of classification was applied to identify increasing dividend announcements. An additional effort is made to include a 'no change' dividend announcements by Malaysian listed companies. If a company pays the same amount of dividend as in the previous year, it would be classified under this category.

A sample of 120 observations consisting of 40 observations for each category from the following sectors: consumer, industrial, trading/services, hotel, properties, plantation, and mining, was selected based on stratified random sampling technique. Financial and utilities sectors were excluded because of their highly regulated nature, different classification of the accounting variables and the relatively large market capitalization that might lead to the size effect problem (Nur-Adiana, 1999). The 120 observations were selected based on the following criteria: (i) the common stock is listed on the Kuala Lumpur Stock Exchange (KLSE). It is included to limit the sample into Malaysian quoted and registered companies so that a true representative is selected; (ii) the selected dividend payments are on cash basis and (iii) there are no other announcements made one day before, during and after the dividend announcements. The last criterion is included to avoid the multiple announcements effect that makes it impossible for a conclusion to be made entirely due to dividend announcements.

All the information required for this study came from secondary data taken from the KLSE library and the Universiti Utara Malaysia library. The announcement dates of the dividends were collected from the Investors Digest and were counter checked with the Daily Diary Newsletter of the KLSE to confirm on the event date and a clean announcement. To examine the effect of dividend announcements, a daily closing adjusted stock price ${ }^{1}$ and the KLSE Composite Index to represent the market returns were collected from Sequencer. One caveat of using Sequencer data is that prices appear consistently as though none of the observations experienced suspended period nor public holidays. To overcome this problem, unit volume of each observation was printed and was counter checked with the adjusted stock prices during the event period, which in this study was 
sixty days surrounding the announcement day. If the unit volume did not change for a particular day, it would either be because the counter was suspended or it was a public holiday. If was a public holiday, that particular day was eliminated from the event period.

\section{Estimation of Abnormal Returns}

The estimation of abnormal returns model utilized in this study is the market adjusted return (MAR) ${ }^{1}$. With the use of MAR, it is assumed that a model of equilibrium expected returns exists where alpha is equal to zero and the average systematic risk is equal to one. This means no estimation of systematic risk or alpha is required bypassing several problems in the Single Index Market Model and Capital Asset Pricing Model approaches ${ }^{3}$.

The MAR procedure starts out by calculating the daily abnormal returns (AR) by comparing the daily stock returns with the returns of the market. The difference between the two returns is known as unexpected or abnormal returns which can be calculated as follows:

$$
A R_{i, t}=R_{i, t}-R_{m, t}
$$

$\mathrm{AR}_{\mathrm{i}, \mathrm{t}}=$ Abnormal returns for stock $\mathrm{i}$ on event day $\mathrm{t}$

$\mathrm{R}_{\mathrm{i}, \mathrm{t}}=\left(\mathrm{P}_{\mathrm{i}, \mathrm{t}}-\mathrm{P}_{\mathrm{i}, \mathrm{l}-1}\right) / \mathrm{P}_{\mathrm{i}, \mathrm{t}-1}=$ The fractional change of stock i's adjusted price $\left(\mathrm{P}_{\mathrm{i}}\right)$ on event day

$t$. This is also known as discrete return by Strong (1992).

$\mathrm{R}_{\mathrm{m}, \mathrm{l}}=\left(\mathrm{K}_{\mathrm{l}}-\mathrm{K}_{\mathrm{t}-1}\right) / \mathrm{K}_{\mathrm{t}-1}=$ The fractional change of the market index $(\mathrm{K})$ on event day $t$ or the market's return on event day $t$.

Trading days prior to the dividend announcements are numbered event days $-1,-2,-3$ and so on; trading day on which an announcement is made is numbered event day 0 ; and event days following the announcement are numbered event days $+1,+2,+3$ and so on. If a stock is suspended on a certain event day, the abnormal returns on that particular day are equal to zero. This is the same as saying that the daily returns for an individual stock is treated as average daily returns during the suspended period. It is computed as:

$$
\begin{aligned}
& R_{i, s}=\left[\left(P_{i, a}-P_{i, a-1}\right) / P_{i, a-1}\right] / t_{i, s} \\
& R_{i, s}=\begin{array}{l}
\text { Average daily returns of stock } i \\
\text { during the suspended period }
\end{array}
\end{aligned}
$$

$P_{i, a-1}=$ Stock i's adjusted price the last trading day before the supended period

$\mathrm{P}_{\mathrm{i}, \mathrm{a}} \quad=$ Stock i's adjusted price the first trading day after the suspended period

$$
\begin{aligned}
t_{i, s}= & \text { The number of days during the } \\
& \text { suspended period of stock } \mathrm{i} \\
& \text { plus the first trading day after } \\
& \text { the suspended period }
\end{aligned}
$$

The next step is to compute the daily crosssectional average abnormal returns $\left(A A R_{t}\right)$ for a specific day, $\mathrm{t}$, which is shown below. It is computed by summing the daily abnormal returns for each observation across companies and dividing this figure with the total observations on that day. This is done for the whole event period or test period.

${ }^{1}$ An adjusted stock price takes into consideration all announcements or events happening in a company such as stock splits, bonus issues, mergers and dividends.

${ }^{2}$ This model has been used by several researchers (Kang, 1990; Kim and Lee, 1990; Marsh, 1977; Norhana et al. 1999; Tsangarakis, 1996).

${ }^{3}$ Further information can be found in some works reported by Brown and Warner $(1980,1985)$, Dimson and Marsh (1986), Dyckman et al. (1984) and Nur-Adiana (2000). 


$$
\begin{aligned}
& A A R_{1}=\sum_{i=1}^{N} A R_{i, t} / N_{t} \\
& \mathrm{~N}_{t}=\text { The number of valid observations } \\
& \quad \text { on event day } t
\end{aligned}
$$

The last step is to sum the cross-sectional average abnormal returns to yield cumulative average abnormal returns (CAAR) for event day $t$ as

$$
\begin{aligned}
& C A A R_{1}=\sum_{k=1-T}^{1} A A R_{1} \\
& \mathrm{~T}=\begin{array}{c}
\text { Some number of event days prior to } \\
\text { day } \mathrm{t}
\end{array}
\end{aligned}
$$

To test the null hypothesis that the daily average abnormal returns on event day $t$ is equal to zero, a t-statistic is calculated. This test determines whether the individual stock returns are statistically different from zero given their distribution about the average. Obviously, some stocks will perform better than the average and some below average. This test will show whether "...there is statistically less than five chances in a hundred that these average returns and the variation about them would have occurred for a group of stocks which did not change in price" (Dawson, 1981, p. 72). This is the same as testing whether there is a significant change in stock prices due to dividend announcements.

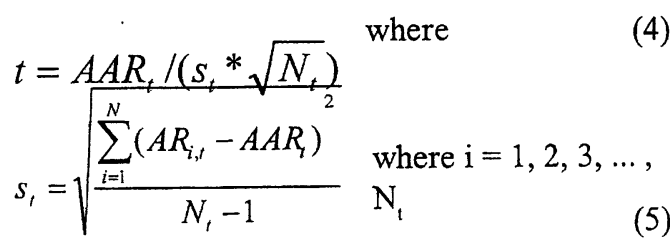

The exact occurrence of information release involves uncertainties, hence, there is a necessity for a test of the cumulative average abnormal re- turns (CAAR) on a specified event period to be executed ${ }^{1}$. The null hypothesis that the CAAR over a period of $T$ days is equal to zero is tested by using a t-statistic which is calculated as below. This test can be used to consider whether there has been any market reaction to dividend announcements.

$$
\begin{gathered}
t_{T}=\left(\text { CAAR }_{T} / T\right) /\left(s_{t} / \sqrt{T}\right) \\
\text { where } \\
s_{t}=\sqrt{\frac{\sum_{t=1}^{T}\left[A A R_{T}-\left(C A A R_{T} / T\right)\right]^{2}}{T-1}} \\
\text { where } t=1,2,3, \ldots, \mathrm{T} \\
\mathrm{CAAR}_{\mathrm{T}}=\begin{array}{l}
\text { Cumulative average abnormal } \\
\text { returns over the T-day } \\
\text { interval }
\end{array}
\end{gathered}
$$
$\mathrm{CAAR}_{\mathrm{T}}=$ Cumulative average abnormal returns over the T-day interval

\section{ANALYSIS OF RESULTS}

The daily average abnormal returns (AARs) and a t-test to determine whether the stock returns associated with increasing, decreasing and no change dividend announcements are statistically different from zero, and the cumulative average abnormal returns (CAARs) are reported in Table 2,3 and 4 respectively.

\section{Increasing Dividend Announcements}

As observed in Table 2, there is a downward trend of abnormal stock returns during the sixty days surrounding the announcement date. In between the event period, there is a mixture of a positive and negative trend of abnormal returns where no exact pattern could be observed. On the announcement date or day $t=0$, the AAR shows a positive

\footnotetext{
'A sixty days event window is selected. This is considered appropriate to detect any unusual movement of the stock prices due to the announcement. This time period is used because evidence from Nur-Adiana's study (1997), which utilized forty days surrounding a rights issue announcement, showed that there is a steep jump of average daily abnormal returns on days $t=-38$ and $t=-36$ before the announcement. It is interesting to know approximately how far back it takes for the stock prices to recognize such an event.
} 
figure of $1.17 \%$ with a t-value of 1.8604 whereas the CAAR stays close to zero at $0.29 \%$. Thereafter a negative trend of abnormal stock returns could be observed that by day $t=+40$ or forty days after the announcement, the CAAR shows a loss of about $-5.18 \%$. On this particular day the AAR experiences a significant loss of $-1.23 \%$ with a tvalue of -1.8701 . The downward trend continues until day $t=+57$, but on day $t=+58$ to +60 , there is a reversal. This pattern can be seen clearly in Figure 1 below. Throughout the 121 days event period, there is a significant change in stock prices due to increasing dividend announcements. These days occurred at $\mathrm{t}=-34,-29,-26,-19,-10,-2,-1$, $0,+24,+29,+37$ and +40 (refer to Table 2 on page 18 , for their t-values). Nonetheless, when a test of the CAAR on a specified event period is executed, the results show that the CAAR for days $t=-1$ to 0 is the only period found to be significant where increasing dividend announcements are associated with a positive cumulative average abnormal return of $1.82 \%$ and a $t$-value of 3.4620 (refer to Table 5). This result suggests that within these two days, there have been some market reactions to dividend announcements.

\section{Decreasing Dividend Announcements}

In contrast to the result presented for the increasing dividend announcements, a clear positive trend of abnormal stock returns is observed for companies announcing a reduction in dividends. As shown in Figure 1 and Table 3 the CAAR at day $t=-60$ started out with a negative value of $-.04 \%$ and slowly rose to $6.2 \%$ on the announcement day, followed with a continuous upward trend to $15.79 \%$ at the end of the event period, that is sixty days after the announcement date. A t-test over different intervals of CAAR is performed and reported in Table 5, showing that the increase in values are statistically significant at the $90 \%$ and $95 \%$ confidence level where the CAAR and t-test over the 121 days event period $(t=-60$ to $t=+60)$ exhibit a value of $15.79 \%$ and 1.9434 respectively. The increasing trend remains consistent through-

\section{Figure 1}

Cumulative average abnormal returns surrounding the announcements of increasing dividend (INCREASINGCAAR), decreasing dividend (DECREASINGCAAR) and no change dividend (NOCHANGECAAR) for 40 observations in each dividend announcement during 1996 to 1999 using the market adjusted return model

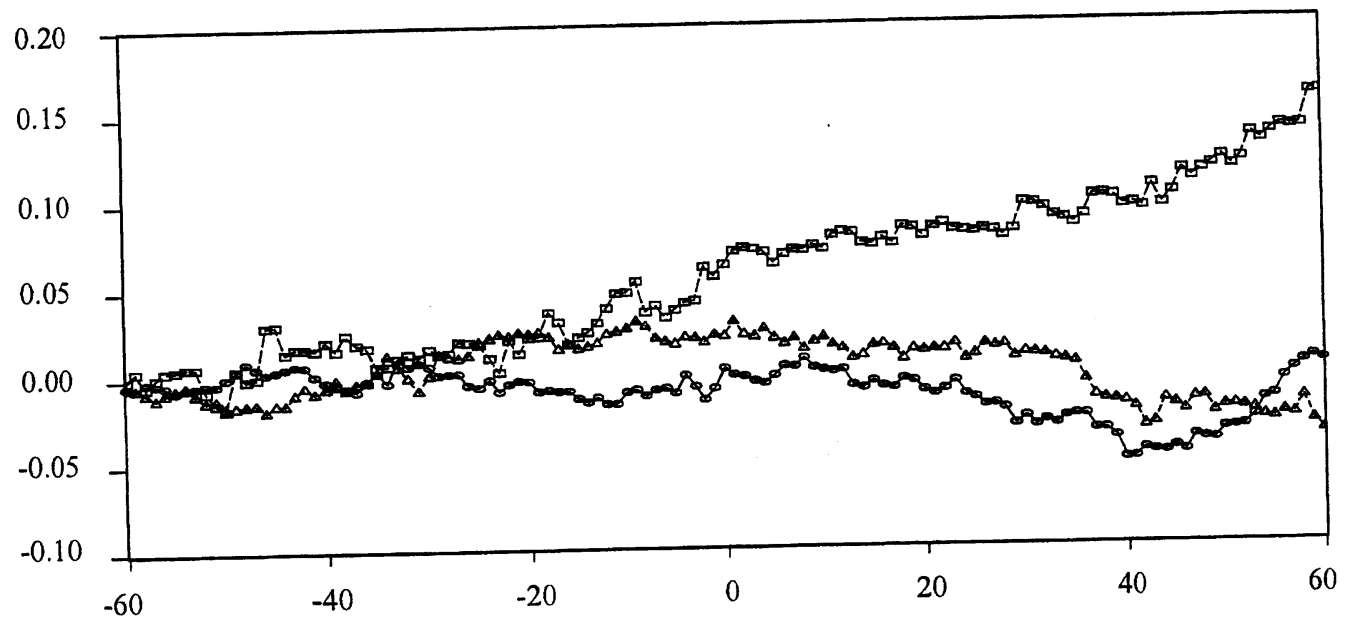

EVENT DAY

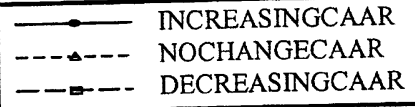


out the event period. A t-test over a few intervals is executed at days $t=-30$ to $+30, t=0$ to +1 and $t=+1$ to +60 all exhibit a CAAR of $8.49 \%, 1.42 \%$ and $9.59 \%$ with a t-value of $1.6065,11.5706$ and 2.1060 . This result suggests that decreasing dividend announcements are associated with positive abnormal returns. It is further supported by the results reported on average abnormal returns (AAR) and the t-test in Table 3. On the average, there is a significant change in stock prices due to the announcements of dividend reduction. A significantly different from zero result occurred at days $t=-52,-49,-46,-44,-24,-16,-8,-2,+1,+37$, $+43,+44,+46,+53$ and +59 . These 15 days reveal that the AARs are statistically different from zero at the $90 \%$ and $95 \%$ confidence level with a t-value of $-2.2928,2.5265,2.8795,-2.5241$, $1.6508,-1.9716,-2.2896,1.7610,2.1389,2.4234$, $2.6469,-2.3062,1.9744,1.6583$ and 2.3067 for the respective days.

\section{No Change.Dividend Announcements}

Table 4, reports on the daily average abnormal returns surrounding the no change dividend announcements. No particular pattern can be detected on these announcements. Almost similar to the results reported on increasing dividend announcements, there exists a mix of downward and upward trends during the 121 days event period. Sixty days before the announcement day until day $\mathrm{t}=-36$, there is a negative trend of abnormal stock returns. Thereafter, a positive trend is observed until day $t=+35$ where the $C A A R=0.42 \%$ with the exceptions of day $t=-32$ and -31 .

Starting from day $t=+36$ to +60 , the CAAR continues to decrease, so that by the end of the event period, the cumulative average abnormal loss is $-3.7 \%$. The daily average abnormal returns on each event day $t$ are not significantly different from zero except for days $\mathrm{t}=-29,-17,+1,+8,+24$, $+26,+36,+37,+44$ and +59 with $t$-values of $1.9396,-2.8018,1.8258,-1.8376,-2.1851$, $1.8137,-3.3718,-2.3437,1.9861$ and -2.1818 respectively. This result implies that there is a significant change in stock returns due to no change dividend announcements on these particular days. Nonetheless, when a t-test of the CAAR on a specified event period is executed (refer to Table 5), none of the interval shows a significant value.
The null hypothesis that the CAAR over a period of $T$ days is equal to zero is accepted. This would mean that there has not been a significant market reaction to no change dividend announcements; but obviously the AAR t-test analysis proves that on the event days which are found to be statistically significant, there are individual stock returns that perform better than the average and some below average.

Comparison of the Effect of Dividend Announcements and the Corporate Finance

\section{Theories}

When the stock market reactions to decreasing dividend announcements are examined, the results are not consistent with the cash flow signaling theory (information content hypothesis) developed by Bhattacharya $(1979,1980)$, John and Williams (1985), and Miller and Rock (1985). Their suggestions that in a world of information asymmetry, an announcement of a decrease in dividends may signal a pessimistic message with respect to a company's future cash flow cannot be supported in the Malaysian context. Investors in the KLSE seem to associate decreasing dividend announcements as good news and react positively. No signal of pessimism about the management's assessment of the future prospects of the company is implied in the reduction of dividends. As for increasing dividend announcements, these are associated with both positive and negative reactions among the Malaysian investors. However, the existence of a statistically significant positive CAAR of $1.82 \%$ one day before and during the announcement day supports the cash flow signaling theory where an increase in dividend signals an increase of a company's future cash flow which brings to an upward movement of its stock price.

As for Jensen's free cash flow hypothesis, the result of increasing dividend announcements by Malaysian listed companies supports his prediction that stock prices will increase if there is unexpected dividend payment. This is because the management has less free cash flow to invest in projects that provide negative NPV. Such a rationale however, cannot explain the market's reaction for companies announcing a reduction in dividend payment. A clear positive trend of abnormal return which induces lead to a CAAR of $15.79 \%$ 
Table 2:

Daily Average Abnormal Returns Surrounding the Increasing Dividend Announcements for 40 Observations (1996 - 1999) using the Market Adjusted Return Model

\begin{tabular}{|c|c|c|c|c|c|c|c|}
\hline Day & AAR & AAR t-test & CAAR & Day & AAR & AAR t-test & CAAR \\
\hline $\begin{array}{l}-60 \\
-59 \\
-58 \\
-57 \\
-56 \\
-55 \\
-54 \\
-53 \\
-52 \\
-51 \\
-50 \\
-49 \\
-48 \\
-47 \\
-46 \\
-45 \\
-44 \\
-43 \\
-42 \\
-41 \\
-40 \\
-39 \\
-38 \\
-37 \\
-36 \\
-35 \\
-34 \\
-33 \\
-32 \\
-31 \\
-30 \\
-29 \\
-28 \\
-27 \\
-26 \\
-25 \\
-24 \\
-23 \\
-22 \\
-21 \\
-20 \\
-19 \\
-18 \\
-17 \\
-16 \\
-15 \\
-14 \\
-13 \\
-12 \\
-11 \\
-10 \\
-9 \\
-8 \\
-7 \\
-6 \\
-5 \\
-4 \\
-3 \\
-2 \\
-1\end{array}$ & $\begin{array}{r}-0.0040 \\
-0.0014 \\
0.0033 \\
-0.0008 \\
-0.0012 \\
-0.0033 \\
0.0018 \\
0.0009 \\
0.0009 \\
-0.0002 \\
0.0037 \\
0.0043 \\
0.0048 \\
-0.0032 \\
-0.0034 \\
0.0014 \\
0.0013 \\
0.0017 \\
-0.0005 \\
-0.0052 \\
-0.0039 \\
-0.0022 \\
-0.0013 \\
-0.0020 \\
0.0058 \\
0.0047 \\
-0.0058 \\
0.0142 \\
-0.0049 \\
0.0020 \\
-0.0020 \\
-0.0050 \\
0.0007 \\
0.0001 \\
-0.0068 \\
-0.0013 \\
0.0042 \\
-0.0068 \\
0.0043 \\
0.0019 \\
-0.0006 \\
-0.0058 \\
0.0006 \\
-0.0007 \\
0.0001 \\
-0.0043 \\
-0.0023 \\
0.0027 \\
-0.0038 \\
0.0000 \\
0.0066 \\
0.0015 \\
-0.0036 \\
0.0032 \\
0.0011 \\
-0.0028 \\
0.0102 \\
-0.0066 \\
-0.0078 \\
0.0065\end{array}$ & $\begin{array}{r}-1.0450 \\
-0.3921 \\
0.9003 \\
-0.2733 \\
-0.4144 \\
-1.0717 \\
0.5503 \\
0.3176 \\
0.2866 \\
-0.0516 \\
0.8941 \\
1.0871 \\
1.3217 \\
-0.6314 \\
-1.1533 \\
0.4815 \\
0.3190 \\
0.5852 \\
-0.1828 \\
-0.9540 \\
-1.0079 \\
-0.4706 \\
-0.3379 \\
-0.4362 \\
1.4853 \\
1.4604 \\
*-2.2748 \\
1.6194 \\
-1.2675 \\
0.5333 \\
-0.6716 \\
*-1.7042 \\
0.2796 \\
0.0242 \\
* *-1813 \\
-0.3982 \\
1.1025 \\
-1.2502 \\
1.1005 \\
0.5541 \\
-0.2467 \\
* *-2.0897 \\
0.2204 \\
-0.1963 \\
0.0509 \\
-0.9886 \\
-0.8759 \\
0.3637 \\
-1.1071 \\
0.0106 \\
* 1.6971 \\
0.2102 \\
-1.0003 \\
0.4992 \\
0.2023 \\
-0.5984 \\
1.3455 \\
-1.4081 \\
*-1.7757 \\
* 1.7076\end{array}$ & $\begin{array}{r}-0.0040 \\
-0.0054 \\
-0.0021 \\
-0.0029 \\
-0.0040 \\
-0.0073 \\
-0.0055 \\
-0.0046 \\
-0.0037 \\
-0.0038 \\
-0.0001 \\
0.0042 \\
0.0090 \\
0.0058 \\
0.0024 \\
0.0039 \\
0.0052 \\
0.0069 \\
0.0064 \\
0.0012 \\
-0.0027 \\
-0.0049 \\
-0.0062 \\
-0.0082 \\
-0.0024 \\
0.0023 \\
-0.0035 \\
0.0106 \\
0.0058 \\
0.0077 \\
0.0057 \\
0.0007 \\
0.0014 \\
0.0015 \\
-0.0053 \\
-0.0066 \\
-0.0024 \\
-0.0092 \\
-0.0049 \\
-0.0030 \\
-0.0036 \\
-0.0094 \\
-0.0088 \\
-0.0094 \\
-0.0093 \\
-0.0136 \\
-0.0159 \\
-0.0132 \\
-0.0170 \\
-0.0170 \\
-0.0104 \\
-0.0089 \\
-0.0125 \\
-0.0093 \\
-0.0083 \\
-0.0111 \\
-0.0009 \\
-0.0075 \\
-0.0153 \\
-0.0088\end{array}$ & $\begin{array}{l}0 \\
1 \\
2 \\
3 \\
4 \\
5 \\
6 \\
7 \\
8 \\
9 \\
10 \\
11 \\
12 \\
13 \\
14 \\
15 \\
16 \\
17 \\
18 \\
19 \\
20 \\
21 \\
22 \\
23 \\
24 \\
25 \\
26 \\
27 \\
28 \\
29 \\
30 \\
31 \\
32 \\
33 \\
34 \\
35 \\
36 \\
37 \\
38 \\
39 \\
40 \\
41 \\
42 \\
43 \\
44 \\
45 \\
46 \\
47 \\
48 \\
49 \\
50 \\
51 \\
52 \\
53 \\
54 \\
55 \\
56 \\
57 \\
58 \\
59 \\
60\end{array}$ & $\begin{array}{r}0.0117 \\
-0.0040 \\
-0.0008 \\
-0.0028 \\
-0.0015 \\
0.0045 \\
0.0053 \\
-0.0005 \\
0.0047 \\
-0.0054 \\
-0.0013 \\
-0.0009 \\
0.0008 \\
-0.0090 \\
-0.0016 \\
0.0041 \\
-0.0034 \\
-0.0009 \\
0.0051 \\
-0.0012 \\
-0.0054 \\
-0.0023 \\
0.0029 \\
0.0044 \\
-0.0077 \\
-0.0019 \\
-0.0044 \\
0.0007 \\
-0.0025 \\
-0.0096 \\
0.0046 \\
-0.0051 \\
0.0028 \\
-0.0021 \\
0.0042 \\
0.0010 \\
-0.0001 \\
-0.0082 \\
0.0000 \\
-0.0046 \\
-0.0123 \\
0.0004 \\
0.0049 \\
-0.0014 \\
-0.0004 \\
0.0027 \\
-0.0024 \\
0.0086 \\
-0.0015 \\
-0.0006 \\
0.0061 \\
0.0006 \\
0.0008 \\
0.0052 \\
0.0100 \\
0.0019 \\
0.0103 \\
0.0050 \\
0.0040 \\
0.0028 \\
-0.0020\end{array}$ & $\begin{array}{r}* 1.8604 \\
-0.9776 \\
-0.2369 \\
-1.0194 \\
-0.4060 \\
1.1005 \\
1.3805 \\
-0.1700 \\
1.2777 \\
-1.2118 \\
-0.4332 \\
-0.2454 \\
0.2117 \\
-1.6346 \\
-0.3671 \\
1.1581 \\
-0.7655 \\
-0.1571 \\
0.9921 \\
-0.2169 \\
-1.4257 \\
-0.7051 \\
0.7610 \\
1.0444 \\
* * 2.2172 \\
-0.4809 \\
-0.9863 \\
0.1962 \\
-0.8428 \\
* *-2.7656 \\
1.2479 \\
-1.1265 \\
0.7642 \\
-0.8597 \\
0.6890 \\
0.2543 \\
-0.0211 \\
*-1.7520 \\
0.0000 \\
-1.2031 \\
*-1.8701 \\
0.1041 \\
1.2777 \\
-0.3567 \\
-0.0781 \\
0.7456 \\
-0.3211 \\
1.4884 \\
-0.5484 \\
-0.1585 \\
1.6077 \\
0.1220 \\
0.1802 \\
0.7257 \\
1.4523 \\
0.3424 \\
0.8102 \\
0.4675 \\
0.9178 \\
0.5078 \\
-0.5098\end{array}$ & $\begin{array}{r}0.0029 \\
-0.0011 \\
-0.0019 \\
-0.0047 \\
-0.0062 \\
-0.0017 \\
0.0036 \\
0.0031 \\
0.0079 \\
0.0024 \\
0.0011 \\
0.0002 \\
0.0010 \\
-0.0080 \\
-0.0096 \\
-0.0055 \\
-0.0089 \\
-0.0097 \\
-0.0046 \\
-0.0058 \\
-0.0112 \\
-0.0136 \\
-0.0106 \\
-0.0063 \\
-0.0140 \\
-0.0159 \\
-0.0203 \\
-0.0196 \\
-0.0222 \\
-0.0318 \\
-0.0272 \\
-0.0323 \\
-0.0295 \\
-0.0316 \\
-0.0275 \\
-0.0265 \\
-0.0266 \\
-0.0349 \\
-0.0349 \\
-0.0395 \\
-0.0518 \\
-0.0514 \\
-0.0465 \\
-0.0478 \\
-0.0482 \\
-0.0456 \\
-0.0479 \\
-0.0394 \\
-0.0409 \\
-0.0415 \\
-0.0353 \\
-0.0347 \\
-0.0340 \\
-0.0288 \\
-0.0187 \\
-0.0168 \\
-0.0065 \\
-0.0015 \\
0.0024 \\
0.0052 \\
0.0032\end{array}$ \\
\hline
\end{tabular}

*significant at $\alpha=0.10 ; * *$ significant at $\alpha=0.05$ 
Table 3:

Daily Average Abnormal Returns Surrounding the Decreasing Dividend announcements for 40 Observations (1996-1999) using the Market Adjusted Return Model

\begin{tabular}{|c|c|c|c|c|c|c|c|}
\hline Day & AAR & AAR t-test & CAAR & Day & AAR & AAR t-test & CAAR \\
\hline 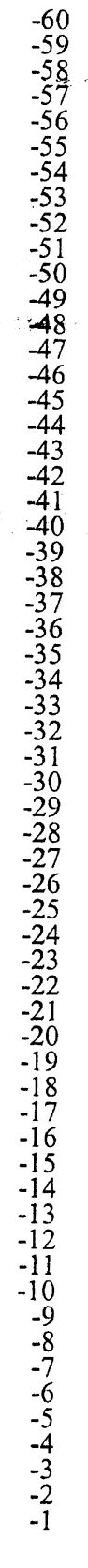 & $\begin{array}{r}-0.0004 \\
0.0050 \\
-0.0088 \\
0.0051 \\
0.0032 \\
0.0011 \\
0.0012 \\
0.0000 \\
-0.0139 \\
-0.0071 \\
-0.0033 \\
0.0228 \\
-0.0059 \\
0.0010 \\
0.0295 \\
0.0006 \\
-0.0161 \\
0.0030 \\
-0.0004 \\
-0.0007 \\
0.0046 \\
-0.0052 \\
0.0092 \\
-0.0057 \\
-0.0017 \\
-0.0111 \\
0.0003 \\
0.0045 \\
0.0024 \\
-0.0022 \\
0.0050 \\
-0.0031 \\
0.0009 \\
0.0063 \\
-0.0005 \\
-0.0014 \\
-0.0075 \\
-0.0083 \\
0.0182 \\
-0.0076 \\
0.0088 \\
0.0005 \\
0.0138 \\
-0.0055 \\
-0.0129 \\
0.0040 \\
0.0028 \\
0.0054 \\
0.0083 \\
0.0084 \\
0.0003 \\
0.0065 \\
-0.0176 \\
0.0039 \\
-0.0072 \\
0.0044 \\
0.0040 \\
0.0011 \\
0.0193 \\
-0.0056 \\
\end{array}$ & $\begin{array}{r}-0.0816 \\
0.6326 \\
-1.3039 \\
0.6479 \\
0.7965 \\
0.1788 \\
0.2352 \\
-0.0054 \\
* *-2.2928 \\
-1.7495 \\
-0.4211 \\
* * 2.5265 \\
-1.1122 \\
0.1856 \\
* * 2.8795 \\
0.0640 \\
* *-2.5241 \\
0.7338 \\
-0.0821 \\
-0.0836 \\
1.1242 \\
-1.2655 \\
1.5329 \\
-0.7670 \\
-0.4117 \\
-2.5426 \\
0.0702 \\
0.9216 \\
0.4466 \\
-0.4323 \\
1.1272 \\
-0.7608 \\
0.0945 \\
0.9825 \\
-0.1068 \\
-0.2845 \\
*-1.6508 \\
-1.3684 \\
0.6200 \\
-0.9254 \\
1.1621 \\
0.0848 \\
1.3701 \\
-1.1460 \\
*-1.9716 \\
0.7762 \\
0.4014 \\
0.7799 \\
1.5318 \\
1.1225 \\
0.0493 \\
0.9753 \\
* * 2896 \\
1.1971 \\
-1.5808 \\
0.7421 \\
0.9275 \\
0.1614 \\
* 1.7610 \\
-0.8671\end{array}$ & $\begin{array}{r}-0.0004 \\
0.0046 \\
-0.0042 \\
0.0009 \\
0.0041 \\
0.0052 \\
0.0064 \\
0.0064 \\
-0.0075 \\
-0.0145 \\
-0.0178 \\
0.0050 \\
-0.0009 \\
0.0001 \\
0.0296 \\
0.0302 \\
0.0141 \\
0.0171 \\
0.0167 \\
0.0160 \\
0.0206 \\
0.0154 \\
0.0246 \\
0.0189 \\
0.0171 \\
0.0060 \\
0.0063 \\
0.0107 \\
0.0131 \\
0.0109 \\
0.0159 \\
0.0128 \\
0.0137 \\
0.0199 \\
0.0195 \\
0.0181 \\
0.0106 \\
0.0023 \\
0.0205 \\
0.0129 \\
0.0218 \\
0.0223 \\
0.0361 \\
0.0306 \\
0.0177 \\
0.0217 \\
0.0245 \\
0.0299 \\
0.0381 \\
0.0465 \\
0.0468 \\
0.0533 \\
0.0357 \\
0.0395 \\
0.0323 \\
0.0367 \\
0.0407 \\
0.0418 \\
0.0612 \\
0.0556\end{array}$ & $\begin{array}{l}0 \\
1 \\
2 \\
3 \\
4 \\
5 \\
6 \\
7 \\
8 \\
9 \\
10 \\
11 \\
12 \\
13 \\
14 \\
15 \\
16 \\
17 \\
18 \\
19 \\
20 \\
21 \\
22 \\
23 \\
24 \\
25 \\
26 \\
27 \\
28 \\
29 \\
30 \\
31 \\
32 \\
33 \\
34 \\
35 \\
36 \\
37 \\
38 \\
39 \\
40 \\
41 \\
42 \\
43 \\
44 \\
45 \\
46 \\
47 \\
48 \\
49 \\
50 \\
51 \\
52 \\
53 \\
54 \\
55 \\
56 \\
57 \\
58 \\
59 \\
60\end{array}$ & $\begin{array}{r}0.0065 \\
0.0077 \\
0.0019 \\
-0.0007 \\
-0.0018 \\
-0.0065 \\
0.0050 \\
0.0026 \\
-0.0003 \\
0.0024 \\
-0.0019 \\
0.0077 \\
0.0022 \\
-0.0008 \\
-0.0059 \\
-0.0010 \\
0.0040 \\
-0.0036 \\
0.0098 \\
-0.0008 \\
-0.0051 \\
0.0054 \\
0.0019 \\
-0.0034 \\
-0.0007 \\
-0.0006 \\
0.0015 \\
-0.0010 \\
-0.0033 \\
0.0036 \\
0.0155 \\
-0.0006 \\
-0.0025 \\
-0.0047 \\
-0.0015 \\
-0.0031 \\
0.0044 \\
0.0116 \\
0.0005 \\
-0.0009 \\
-0.0055 \\
0.0009 \\
-0.0022 \\
0.0130 \\
-0.0112 \\
0.0068 \\
0.0126 \\
-0.0046 \\
0.0048 \\
0.0025 \\
0.0047 \\
-0.0054 \\
0.0039 \\
0.0145 \\
-0.0040 \\
0.0051 \\
0.0035 \\
-0.0011 \\
0.0009 \\
0.0191 \\
0.0005\end{array}$ & $\begin{array}{r}1.4816 \\
* * 2.1389 \\
0.4671 \\
-0.1895 \\
-0.4005 \\
-1.0855 \\
1.1986 \\
0.4508 \\
-0.0659 \\
0.4894 \\
-0.3676 \\
1.1569 \\
0.3718 \\
-0.2139 \\
-0.9363 \\
-0.2599 \\
0.4292 \\
-0.6120 \\
1.3571 \\
-0.1594 \\
-1.2101 \\
0.9740 \\
0.3499 \\
-0.7829 \\
-0.2054 \\
-0.1714 \\
0.4052 \\
-0.2453 \\
-0.6302 \\
0.7654 \\
1.5470 \\
-0.1348 \\
-0.6317 \\
-0.9853 \\
-0.3281 \\
-0.7524 \\
0.9308 \\
* * 2.4234 \\
0.1052 \\
-0.2805 \\
-0.9182 \\
0.2627 \\
-0.4488 \\
* * 2.6469 \\
* *-2.3062 \\
0.9727 \\
* 1.9744 \\
-0.6876 \\
0.9008 \\
0.3704 \\
1.1168 \\
-1.3217 \\
0.7758 \\
* 1.6583 \\
-0.8068 \\
0.9390 \\
0.5508 \\
-0.1693 \\
0.1284 \\
* 2.3067 \\
0.0729\end{array}$ & $\begin{array}{l}0.0620 \\
0.0698 \\
0.0717 \\
0.0710 \\
0.0692 \\
0.0627 \\
0.0677 \\
0.0703 \\
0.0700 \\
0.0724 \\
0.0705 \\
0.0782 \\
0.0804 \\
0.0796 \\
0.0737 \\
0.0727 \\
0.0766 \\
0.0730 \\
0.0829 \\
0.0821 \\
0.0770 \\
0.0824 \\
0.0843 \\
0.0809 \\
0.0801 \\
0.0795 \\
0.0810 \\
0.0800 \\
0.0768 \\
0.0804 \\
0.0959 \\
0.0953 \\
0.0928 \\
0.0881 \\
0.0866 \\
0.0835 \\
0.0880 \\
0.0995 \\
0.1000 \\
0.0990 \\
0.0935 \\
0.0945 \\
0.0923 \\
0.1052 \\
0.0940 \\
0.1009 \\
0.1135 \\
0.1089 \\
0.1137 \\
0.1162 \\
0.1209 \\
0.1155 \\
0.1194 \\
0.1339 \\
0.1299 \\
0.1350 \\
0.1385 \\
0.1375 \\
0.1383 \\
0.1574 \\
0.1580\end{array}$ \\
\hline
\end{tabular}

*significant at $\alpha=0.10 ; * *$ significant at $\alpha=0.05$ 
Table 4:

Daily Average Abnormal Returns Surrounding the No Change Dividend announcements for 40 Observations (1996 -1999) using the Market Adjusted Return Model

\begin{tabular}{|c|c|c|c|c|c|c|c|}
\hline Day & AAR & AAR t-test & CAAR & Day & AAR & AAR t-test & CAAR \\
\hline $\begin{array}{l}-60 \\
-59 \\
-58 \\
-57 \\
-56 \\
-55 \\
-54 \\
-53 \\
-52 \\
-51 \\
-50 \\
-49 \\
-48 \\
-47 \\
-46 \\
-45 \\
-44 \\
-43 \\
-42 \\
-41 \\
-40 \\
-39 \\
38 \\
-37 \\
-36 \\
-35 \\
-34 \\
-33 \\
-32 \\
-31 \\
-30 \\
-29 \\
-28 \\
-27 \\
-26 \\
-25 \\
-24 \\
-23 \\
-22 \\
-21 \\
-20 \\
-19 \\
-18 \\
-17 \\
-16 \\
-15 \\
-14 \\
-13 \\
-12 \\
-11 \\
-10 \\
-9 \\
-8 \\
-7 \\
-6 \\
-5 \\
-4 \\
-3 \\
-2 \\
-1\end{array}$ & $\begin{array}{r}-0.0043 \\
-0.0007 \\
-0.0027 \\
-0.0034 \\
0.0031 \\
0.0021 \\
0.0018 \\
-0.0047 \\
-0.0044 \\
0.0010 \\
-0.0040 \\
-0.0001 \\
0.0009 \\
0.0007 \\
-0.0041 \\
0.0035 \\
0.0000 \\
0.0058 \\
0.0042 \\
-0.0036 \\
0.0027 \\
0.0051 \\
-0.0059 \\
0.0033 \\
0.0010 \\
0.0054 \\
0.0098 \\
-0.0067 \\
-0.0060 \\
-0.0076 \\
0.0084 \\
0.0123 \\
-0.0016 \\
-0.0005 \\
0.0014 \\
0.0073 \\
0.0022 \\
0.0022 \\
-0.0012 \\
0.0021 \\
-0.0009 \\
0.0008 \\
-0.0026 \\
-0.0070 \\
0.0033 \\
-0.0030 \\
0.0012 \\
0.0019 \\
0.0050 \\
0.0013 \\
0.0017 \\
0.0040 \\
-0.0029 \\
-0.0067 \\
-0.0020 \\
-0.0016 \\
0.0039 \\
-0.0005 \\
-0.0026 \\
0.0042\end{array}$ & $\begin{array}{r}-0.9193 \\
-0.2175 \\
-0.5973 \\
-0.9002 \\
0.8176 \\
0.7897 \\
0.5527 \\
-1.1010 \\
-1.0103 \\
0.2746 \\
-1.2307 \\
-0.0157 \\
0.2285 \\
0.3096 \\
-1.0945 \\
0.4215 \\
0.0050 \\
1.6962 \\
1.1222 \\
-1.2774 \\
0.7676 \\
1.0470 \\
-1.2783 \\
0.5844 \\
0.2338 \\
1.0802 \\
0.8956 \\
-1.5018 \\
-1.0075 \\
-1.5130 \\
1.7401 \\
* 1.9396 \\
-0.4512 \\
-0.0990 \\
0.3702 \\
1.3099 \\
0.5413 \\
0.4036 \\
-0.2460 \\
0.5363 \\
-0.2909 \\
0.3051 \\
-0.5488 \\
* * 2.8018 \\
0.9623 \\
-1.0545 \\
0.3552 \\
0.6058 \\
0.8141 \\
0.4512 \\
0.4655 \\
1.1394 \\
-0.8678 \\
-1.3621 \\
-0.3343 \\
-0.5303 \\
0.8125 \\
-0.1436 \\
-0.6391 \\
1.1547\end{array}$ & $\begin{array}{r}-0.0043 \\
-0.0050 \\
-0.0078 \\
-0.0111 \\
-0.0080 \\
-0.0060 \\
-0.0042 \\
-0.0088 \\
-0.0132 \\
-0.0122 \\
-0.0163 \\
-0.0163 \\
-0.0154 \\
-0.0148 \\
-0.0189 \\
-0.0154 \\
-0.0154 \\
-0.0096 \\
-0.0054 \\
-0.0090 \\
-0.0063 \\
-0.0011 \\
-0.0071 \\
-0.0038 \\
-0.0028 \\
0.0026 \\
0.0124 \\
0.0057 \\
-0.0003 \\
-0.0080 \\
0.0005 \\
0.0128 \\
0.0112 \\
0.0107 \\
0.0121 \\
0.0194 \\
0.0216 \\
0.0238 \\
0.0226 \\
0.0247 \\
0.0238 \\
0.0246 \\
0.027 \\
0.0208 \\
0.0187 \\
0.0171 \\
0.0210 \\
0.0206 \\
0.0180 \\
0.0226 \\
0.0150 \\
0.0182 \\
0.0153 \\
0.0165 \\
0.0184 \\
0.0234 \\
0.0263 \\
\end{array}$ & $\begin{array}{l}0 \\
1 \\
2 \\
3 \\
4 \\
5 \\
6 \\
7 \\
8 \\
9 \\
10 \\
11 \\
12 \\
13 \\
14 \\
15 \\
16 \\
17 \\
18 \\
19 \\
20 \\
21 \\
22 \\
23 \\
24 \\
25 \\
26 \\
27 \\
28 \\
29 \\
30 \\
31 \\
32 \\
33 \\
34 \\
35 \\
36 \\
37 \\
38 \\
39 \\
40 \\
41 \\
42 \\
43 \\
44 \\
45 \\
46 \\
47 \\
48 \\
49 \\
50 \\
51 \\
52 \\
53 \\
54 \\
55 \\
56 \\
57 \\
58 \\
59 \\
60\end{array}$ & $\begin{array}{r}-0.0009 \\
0.0085 \\
-0.0076 \\
-0.0013 \\
0.0043 \\
-0.0053 \\
-0.0032 \\
0.0030 \\
-0.0063 \\
0.0041 \\
0.0024 \\
-0.0044 \\
-0.0022 \\
-0.0055 \\
0.0013 \\
0.0058 \\
0.0005 \\
-0.0026 \\
-0.0061 \\
0.0057 \\
-0.0012 \\
0.0009 \\
-0.0001 \\
0.0032 \\
-0.0088 \\
0.0025 \\
0.0061 \\
-0.0016 \\
0.0009 \\
-0.0070 \\
0.0026 \\
-0.0005 \\
-0.0007 \\
-0.0022 \\
-0.0008 \\
-0.0015 \\
-0.0104 \\
-0.0092 \\
-0.0021 \\
-0.0006 \\
-0.0010 \\
-0.0035 \\
-0.0105 \\
0.0017 \\
0.0134 \\
-0.0027 \\
-0.0038 \\
0.0072 \\
0.0006 \\
-0.0091 \\
0.0032 \\
0.0008 \\
-0.0012 \\
-0.0016 \\
-0.0040 \\
-0.0010 \\
0.0034 \\
-0.0013 \\
0.0098 \\
-0.0135 \\
-0.0056\end{array}$ & $\begin{array}{r}-0.2106 \\
* 1.8258 \\
-1.4105 \\
-0.5223 \\
0.8012 \\
-1.1858 \\
-0.8705 \\
0.6916 \\
*-1.8376 \\
1.4845 \\
0.9313 \\
-1.1811 \\
-0.5965 \\
-0.8405 \\
0.2792 \\
0.9303 \\
0.1697 \\
-0.3891 \\
-1.7997 \\
1.0705 \\
-0.5616 \\
0.2958 \\
-0.0272 \\
0.5259 \\
* *-2.1851 \\
0.6067 \\
* 1.8137 \\
-0.1840 \\
0.2078 \\
-1.6674 \\
0.6362 \\
-0.1701 \\
-0.2430 \\
-0.5268 \\
-0.2277 \\
-0.4703 \\
* *-3.3718 \\
* *-2.3437 \\
-0.5615 \\
-0.1421 \\
-0.2020 \\
-0.9426 \\
-1.8188 \\
0.3732 \\
* 1.9861 \\
-0.6541 \\
-0.9073 \\
1.3951 \\
0.0886 \\
-1.7597 \\
0.6557 \\
0.2884 \\
-0.3783 \\
-0.3941 \\
-1.4397 \\
-0.2698 \\
0.5383 \\
-0.2741 \\
1.4052 \\
* *-2.1818 \\
-1.0375\end{array}$ & $\begin{array}{r}0.0213 \\
0.0298 \\
0.0222 \\
0.0209 \\
0.0252 \\
0.0200 \\
0.0167 \\
0.0198 \\
0.0135 \\
0.0176 \\
0.0200 \\
0.0156 \\
0.0134 \\
0.0079 \\
0.0092 \\
0.0150 \\
0.0156 \\
0.0130 \\
0.0069 \\
0.0126 \\
0.0113 \\
0.0123 \\
0.0122 \\
0.0154 \\
0.0066 \\
0.0091 \\
0.0152 \\
0.0135 \\
0.0144 \\
0.0074 \\
0.0099 \\
0.0095 \\
0.0088 \\
0.0065 \\
0.0057 \\
0.0042 \\
-0.0062 \\
-0.0155 \\
-0.0175 \\
-0.0181 \\
-0.0192 \\
-0.0227 \\
-0.0332 \\
-0.0315 \\
-0.0181 \\
-0.0208 \\
-0.0246 \\
-0.0174 \\
-0.0168 \\
-0.0259 \\
-0.0227 \\
-0.0219 \\
-0.0232 \\
-0.0247 \\
-0.0287 \\
-0.0297 \\
-0.0263 \\
-0.0277 \\
-0.0179 \\
-0.0314 \\
-0.0370\end{array}$ \\
\hline
\end{tabular}

*significant at $\alpha=0.10$;** significant at $\alpha=0.05$ 
Table 5

T-Test Over Different Intervals of Cumulative Average Abnormal Returns (CAARs)

\begin{tabular}{|l|r|r|r|r|r|r|}
\hline \multicolumn{1}{|c|}{ Interval } & \multicolumn{2}{|c|}{ Increasing } & \multicolumn{2}{c|}{ Decreasing } & \multicolumn{2}{c|}{ No Change } \\
\hline & CAAR & t-test & CAAR & t-test & CAAR & $t$-test \\
\hline Days $\mathrm{t}=-60$ to +60 & 0.0032 & 0.0640 & 0.1579 & $* * 1.9434$ & -0.0371 & -0.7090 \\
Days $\mathrm{t}=-30$ to +30 & -0.0349 & -0.9894 & 0.0849 & $* 1.6065$ & 0.0179 & 0.5258 \\
Days $\mathrm{t}=-10$ to +10 & 0.0181 & 0.7344 & 0.0240 & 0.7304 & -0.0047 & -0.2338 \\
Days $\mathrm{t}=-1$ to +1 & 0.0142 & 1.0257 & 0.0086 & 0.6746 & 0.0118 & 1.4476 \\
Days $\mathrm{t}=-60$ to -1 & -0.0088 & -0.2677 & 0.0555 & 0.8236 & 0.0222 & 0.6723 \\
Days $\mathrm{t}=-30$ to 0 & -0.0049 & -0.1803 & 0.0511 & 1.1058 & 0.0292 & 1.2909 \\
Days $\mathrm{t}=-14$ to 0 & 0.0165 & 0.7332 & 0.0404 & 1.2522 & 0.0060 & 0.4766 \\
Days $\mathrm{t}=-1$ to 0 & 0.0182 & $* 3.4620$ & 0.0009 & 0.0732 & 0.0033 & 0.6464 \\
Days $\mathrm{t}=0$ to +1 & 0.0077 & 0.4926 & 0.0142 & $* * 11.5706$ & 0.0076 & 0.8079 \\
Days $\mathrm{t}=0$ to +14 & -0.0008 & -0.0410 & 0.0181 & 1.0660 & -0.0130 & -0.7148 \\
Days $\mathrm{t}=0$ to +30 & -0.0183 & -0.7002 & 0.0403 & 1.4931 & -0.0122 & -0.4848 \\
Days $\mathrm{t}=+1$ to +60 & 0.0003 & 0.0091 & 0.0959 & $* * 2.1060$ & -0.0583 & -1.4508 \\
\hline
\end{tabular}

over the 121 days event period shows that the KLSE investors do not appear to associate a decrease in dividend payment with more opportunities for the management of a company to overinvest its free cash flow. It is likely that in a developing market such as Malaysia, the free cash flow would be invested in profitable projects to enhance the growth of a company. This explanation would also mean that the agency cost theory developed by Easterbrook (1984) cannot be supported in the Malaysian context. Surprisingly, his assertion that a reduction of dividend payment would encourage managers to misuse company's resources through an increase in perquisites does not appear to be relevant as a significantly positive abnormal return is observed for Malaysian listed companies announcing dividend decreases.

\section{Comparison of Market Reaction to}

Dividend Announcements with Previous Studies

In the United States (US), the empirical evidence revealed that an announcement of a dividend increase (decrease) is normally followed by an increase (decrease) in stock prices. This is shown in the work of Aharony and Swary (1980), Impson and Karafiath (1992) and Impson (1997). The results of these studies provide support for the cash flow signaling theory. Similar results are presented in the United Kingdom (UK) where Lonie et al. (1996) found that announcements of dividend increase provide an abnormal return of $1.42 \%$ at $t=$ 1 and $0.61 \%$ at $t=0$ with a $t$-value of 5.11 and 3.80 respectively; whereas dividend decrease is associated with a negative abnormal return of $-2.15 \%$ $(\mathrm{t}$-value $=-2.68)$ at $\mathrm{t}=-1$; and for no change in dividend, positive abnormal return of $1.44 \%$ ( $t$ value $=2.34$ ) is observed at day $t=-1$. The magnitude of the abnormal return loss for dividend-decreasing companies is similar to that reported by Aharony and Swary (1980). Another study in the UK by Balachandran et al. (1999) also presented consistent evidence as in the US. Their studies on interim dividend reductions showed a statistically significant price decline among the UK companies.

Based on the current finding of this study, decreasing dividend announcements are associated with a significantly positive cumulative average abnormal return in the Malaysian stock market. The existence of an up ward movement in 
CAAR does not tally with the results reported in the US, UK and Malaysia. Mansor and Subramaniam's findings on dividend decrease contradict with what is found in this study needs to be explained. However, an observation of a significantly positive CAAR of $1.82 \%$ one day before and during the announcement day for increasing dividend announcements among the Malaysian listed companies concurs with the findings presented in the US, UK as well as Mansor and Subramaniam' work in Malaysia.

\section{CONCLUSION}

There is extensive empirical work on stock market reactions to dividend announcements in developed markets, particularly in the US. The same cannot true for an emerging market like Malaysia. This study might be one of the most comprehensive investigations of this topic using the KLSE listed companies. The announcements of final dividend from the year 1996 to 1999 are categorized into increasing, decreasing and no change. Based on the cash flow signaling theory, Jensen's free cash flow hypothesis and agency cost theory, it is expected that a dividend increase (decrease) will lead to a positive (negative) abnormal return, and a no change in dividend logically would provide no abnormal share price movements.

A standard event study methodology is used to investigate the effect of these announcements. The findings provide no evidence that decreasing dividend announcements are associated with a negative price effect, which means none of the theories can be applied in the Malaysian context. The existence of a significantly positive abnormal return for increasing dividend announcements nevertheless concurs with the corporate financial theories and empirical evidence provided in the US and UK. As for the no change dividend announcements, since no clear pattern of CAAR is observed and there are mixed positive and negative reactions among the Malaysian investors, conclusive support cannot be forwarded.

\section{REFERENCES}

Aharony, J. and Swary, I. (1980). Quarterly Divi dend and Earnings Announcements and Stockholders' Returns: An Empirical Analysis. Journal of Finance, 35(1), 1-12.

Asquith, P. and Mullins J r., D. (1983). The Impact of Initiating Dividend Payments on Shareholders' Wealth. Journal of Business, 56, 77-96.

Balachandran, B., Cadle, J. and Theobald, M. (1999). Analysis of Price Reactions to Interim Dividend Reductions-A Note. Applied Financial Economics, 9, 305-314.

Bhattacharya, S. (1979). Imperfect Information, Dividend Policy and the Bird in the Hand Fallacy. Bell Journal of Economics, 10(1), 259-270.

Bhattacharya, S. (1980). Nondissipative Signaling Structures and Dividend Policy. Quarterly Journal of Economics, 95, 1-24.

Brown, S. J. and Warner, J. B. (1980). Measuring Security Price Performance. Journal of Financial Economics, 8, 205-258.

Brown, S. J. and Warner, J. B. (1985). Using Daily Stock Returns: The Case of Event Studies. Journal of Financial Economics, 12, 3-31.

Charest, G. (1978). Dividend Information, StockReturns and Market Efficiency. Journal of Financial Economics, 6, 297-330.

Dawson, S. M. (1981). A Test of Stock Recommedation and Market Efficiency for the KLSE. Singapore Management Review, 69-72.

Dimson, E. and Marsh, P. (1986). Event Study Meth odologies and the Size Effect. Journal of Financial Economics, 17, 113-142. 
Dielman, T. E. and Oppenheimer, H. R. (1984). An Examination of Investor Behavior During Periods of Large Dividend Changes. Journal of Financial and Quantitative Analysis, 19 (2), 197-216.

Dyckman, T. M., Philbrick, D. and Stephan, J. (1984). A Comparison of Event Study Methodologies Using Daily Stock Returns: A Simulation Approach. Journal of Accounting Research, 22, 1-30.

Eades, K., Hess, P. and Kim, E. (1985). Market Rationality and Dividend Announcements. Journal of Financial Economics, 14, 581-604.

Easterbrook, F. (1984). Two Agency-Cost Explana tions of Dividends. American Economic Review, 74, 650-659.

Fama, E. F., Fisher, L., Jensen, M. and Roll, R. (1969). The Adjustment of Stock Prices to New Information. International Economic Review, 10 (1), 1-21.

Ghosh, C. and Woolridge, J. R. (1988). An Analysis of Shareholder Reaction to Dividend Cuts and Omissions. Journal of Financial search, 11 (Winter), 281-294.

Glen, et al. (1997). Corporate Dividend Policy in Emerging Markets. Emerging Markets Quarterly, 1(4); 5-20.

Healy, P. M. and Palepu, K. G. (1988). Earnings In- formation Conveyed By Dividend Initiations and Omissions. Journal of Financial Economics, 21, 149-176.

Impson, C. M. (1997). Market Reaction to ividend Decrease Announcements: Public Utilitie vs. Unregulated Industrial Firms. The Journal of Financial Research, 20, 407-422.

Impson, C. M. and Karafiath, I. (1992). A Note on the Stock Market Reaction to Dividend Announcements. The Financial Review, 12(2), 259-271.
Jensen, M. (1986). Agency Costs of Free Cash Flows, Corporate Finance and Takeovers. American Economic Review, 76, 323-329.

Jin, Zhenhu. (2000). On the Differential Market Re- action to Dividend Initiations. The Quarterly Review of Economics and Finance, 12, 263-277.

John, K. and Williams, J. (1985). Dividends, Dilution and Taxes: A Signaling Equilibrium. Journal of Finance, 40, 1053-1070.

Kang, H. (1990). Effects of Seasoned Equity Offer -ings in Korea on Shareholder's Wealth $P a$ cific Basin: Capital Markets Research, 2, 265282.

Kim, E. H. and Lee, Y. K. (1990). Issuing Stocks in Korea. Pacific Basin: Capital Markets Research, 2, 243-253.

Lipson, M. L., Maquieira, C. P. and Megginson, W. (1998). Dividend Initiations and Earnings Surprises. Financial Management, 27(3),36-45.

Lonie, A. A., Abeyratna, G., Power, D. M and S incla ir, C.D.(1996). The S tock MarketReaction to Dividend Announcements: A UK Study of Complex Market Signals. Journal of Economic Studies, 23(1), 32 52.

Mansor, M. I. and Subramaniam, V. (1992). The Effects of Dividends and Earnings Announcements on Stock Prices in the Malaysian Stock Market. Malaysian Journal of Economic Studies, 29(1), 35-49.

Marsh, P. (1977). An Analysis of Equity Rights Isues on the London Stock Exchange. Unpublished doctoral dissertation. London Graduate School of Business Studies, University of London.

Michaely, R., Thaler, R. and Womack, K. (1995). Price Reactions to Dividend Initiations and Omissions: Overreaction or Drift? Journal of Finance, 50, 573-608. 
Miller, M. H. and Modigliani, F. (1961). Dividend Policy, Growth and the Valuation of Shares. Journal of Business, 34(4), 411-433.

Miller, M. and Rock, K. (1985). Dividend Policy Under Asymmetric Information. Quarterly Journal of Economics, 95, 1031-1051.

Mitra, D. and Owers, J. E. (1995). Dividend Initiation Announcement Effects and the Firms's Information Environment. Journal of Business and Accounting, 22(4), 551-573.

Norhana, S., Mohamed, A. and Annuar, M. N. (1999). Economic Influence on Rights Issue Announcement Behavior in Malaysia. $P a-$ cific-Basin Finance Journal, 7, 405-427.

Nur-Adiana, H. A. (1997). A Cross-Sectional Analysis Between the Effect of Rights Issue Announcements and Its Determinants. Capital Markets Review, 5(1), 1-22.

Nur-Adiana, H. A. (1999). An Empirical Investigation of the Effect of Rights Issue Announcements on Share Returns and the Determinants of Abnormal Returns on the Kuala Lumpur Stock Exchange. Unpublished doctoral dissertation. Aston University.

Nur-Adiana, H. A. (2000). Event Study Analysis and Market Efficiency: A Critical Review. Utara Management Review, 1(2), 1-28.
Pettit, R. R. (1972). Dividend Announcements, Security Performance, and Capital Market Efficiency. Journal of Finance, 993-1007.

Ross, S. A., Westerfield, R. W. and Jaffe, J. (1999). Corporate Finance Fifth Edition. Boston: Irwin/McGraw-Hill.

Strong, N. (1992). Modelling Abnormal Returns: A Review Article. Journal of Business \& Accounting, 19(4), 57-79.

Tsangarakis, N. V. (1996). Shareholders Wealth Effects of Equity Issues in Emerging Markets: Evidence from Rights Offerings in Greece. Financial Management, 25, 21-32.

Venkatesh, P. C. (1989). The Impact of Dividend Initiation on the Information Content of Earnings Announcements and Return Volatility. Journal of Business, 62, 175-197.

Woolridge, J. (1983). Dividend Changes and Security Prices. Journal of Finance, 38, 16071615.

Yoon, P. S. and Starks, L. (1995). Signaling, Investment Opportunities and Dividend Announcements. The Review of Financial Studies, 8, 995-1018. 